Received:

$22-V-2020$

Accepted:

2-IX-2020

Published Online: 21-IX-2020

\section{Nasal Wall Oriented Implants for All-on-4 Fix-Detachable Maxillary} Reconstruction

\section{Implantes nasales orientados a la pared para una reconstrucción} maxilar desmontable fija All-on-4

Jean Uhlendorf DDS, MSc ${ }^{1}$; Carolina A. Cartelli DDS, MScㄹ;

Larissa C. Trojan DDS, MSc, PhD1; Geninho Thomé DDS, MSc, PhD;

Marcos B. Moura DDS, MSc ${ }^{1}$

1. Department of Implantology, ILAPEO College, Curitiba, Parana, Brazil.

Correspondence to: MSc. Marcos B. Moura - boaventura.mm@hotmail.com

ABTRACT: Immediate loading of full-arch prostheses on dental implants in the upper arch is challenging, as the bone is of low quality and obtaining sufficient torque may be difficult. The purpose of this case report is to describe the rehabilitation of a fullarch by means of placement of four internal tapered connection tilted implants and immediate loading. A 65-year-old man sought dental care with a partially edentulous upper arch. The teeth presented mobility and were extracted. In a second step, two conventional-length implants were placed in the anterior region and two tilted and nasal wall-directed extra-long implants in the posterior region. The insertion torques of $60 \mathrm{~N} . \mathrm{cm}$ allowed the installation of an immediate prosthesis (hybrid). The clinical case report suggests that the placement of tilted and extra-long implants in the paranasal bone and immediate loading may be a viable option for rehabilitation of the edentulous upper arch.

KEYWORDS: Dental implant; Dental materials; Dental Prosthesis; Immediate dental implant loading; Tooth loss; Torque. 
RESUMEN: La carga inmediata de prótesis de arco completo en implantes dentales en el arco superior es un desafío, ya que el hueso es de baja calidad y puede ser difícil obtener un par suficiente. El propósito de este reporte de un caso es describir la rehabilitación de un arco completo mediante la colocación de cuatro implantes inclinados de conexión cónica interna y carga inmediata. Un hombre de 65 años buscó atención dental con un arco superior parcial sin dientes. Los dientes presentaron movilidad y fueron extraídos. En un segundo paso, se colocaron dos implantes de longitud convencional en la región anterior y dos implantes extralargos inclinados y dirigidos a la pared nasal en la región posterior. Los pares de inserción de 60 N.cm permitieron la instalación de una prótesis inmediata (híbrida). El informe del caso clínico sugiere que la colocación de implantes inclinados y extralargos en el hueso paranasal y la carga inmediata pueden ser una opción viable para la rehabilitación del arco superior desdentado.

PALABRAS CLAVE: Implante dental; Materiales dentales; Prótesis dental; Carga inmediata de implantes dentales; Pérdida de dientes; Esfuerzo de torsión.

\section{INTRODUTION}

The reduced and inadequate bone volume occurs due to the absence of stimulus in the residual bone after tooth extraction, infections, trauma and pneumatization of the maxillary sinuses (1). Retention of removable prostheses is compromised due to accelerated bone loss and reduced and inadequate bone volume, which occurs mainly in the upper jaws (2). To increase bone volume, methods such as autogenous bone grafts, guided bone regeneration, allogeneic material and combinations of these procedures with delayed loading have been used $(3,4)$.

Patients are increasingly demanding, seeking faster and less invasive treatments, and the possibility of immediate loading should be evaluated (5). The upper jaw bone is normally of low quality and reabsorbs faster than the lower jaw bone, resulting in difficulties in obtaining the primary stability so essential for immediate loading and osseointegration (6). The placement torque value of $35 \mathrm{~N} . \mathrm{cm}$ has been accepted for immediate loading of implants (5).
To place dental implants in the resorbed upper jaw, an orthopedic principle that has been used is bicorticalization, defined as the use of the portion of the basal cortical to retain the implant (6). The use of long implants facilitates obtaining bicorticalization and offers greater primary stability (5-7). Thus, anchoring in the cortical bone of the nasal cavity and anterior sinus wall is possible when long-length implants are inserted in the region of first and second premolars (apex anchored in the nasal cortical floor) (8). In addition, the placement of tilted implants can increase the antero-posterior propagation, providing satisfactory posterior support for the prosthesis (6-8). This inclination of the implants also reduces the length of the cantilever and generates a better load distribution (6). Finally, the increase in bone-implant contact provides better anchorage and good primary stability that enables immediate loading, which is important for continuous remodeling of the soft tissues and bone around the implants (5-7).

The internal tapered connection implants that present platform switching have been widely indicated for presenting characteristics that favor 
the biological response of the peri-implant tissue, such as of the gap existing at the implant-abutment interface as well as the loosening of screws $(9,10)$, a recurrent problem in external hexagon connection implants (10). The objective of this case report was to describe a clinical case of an upper arch fully rehabilitated with anterior conventional-length implants and distal extra-long implants, placed tilted with anchoring in the paranasal bone and immediately loaded.

\section{CASE REPORT}

A 65-year-old male patient attended the Department of Implantology at ILAPEO College (Curitiba, Brazil) presenting mobility of the remaining teeth of the upper arch. In the first appointment, general health information, CT scan, panoramic radiography and occlusion assessment were obtained. Intra and extra-oral photographs were taken, and serum tests were requested. Written informed consent was obtained from the patient to publish his case.

\section{INTRA-ORAL AND RADIOGRAPHIC EXAMINATION}

Clinically, the patient presented aesthetic and functional impairment and excessive exposure of the gingival tissue. The patient wore a removable partial denture that presented a mismatch, and only teeth \#11, \#12, \#13, \#14, \#15 and \#21 were present, with grade III mobility. The lower arch presented a fixed full arch hybrid prosthesis previously placed (Figure 1).

Radiographically, the patient had a partially edentulous upper arch, generalized bone loss, low quality bone (type III) and pneumatization of the right maxillary sinus (Figure 2.A).

\section{TREATMENT PLAN}

The treatment proposed by the team of professionals was the placement of two conventional-length implants in the anterior region and two distal tilted and nasal wall-directed extralong implants to support a fixed full-arch hybrid prosthesis with immediate loading. The purpose of treatment in this case was to restore the patient's function and aesthetic appearance, in addition to reconstructing the occlusion with the reestablishment of the vertical dimension.

\section{INITIAL PROSTHETIC PHASE}

The remaining teeth were extracted 6 months prior to implant rehabilitation procedures in the upper arch (Figure 2.B).

Anatomical impression of the upper and lower dental arches was performed. Then, the upper wax orientation plane was adjusted, the models were mounted on a semi-adjustable articulator, the color was selected, and the teeth were tested in wax. Subsequently, the patient returned for try-in of the multifunctional guide.

\section{SURGICAL PHASE}

After anesthesia of the upper jaw, an incision was performed in the bone crest followed by a buccal and palatal detachment of a flap from the right molar to the left molar. Horizontal osteotomy was performed to avoid esthetics and functional problems. The implant sites preparation was carried out according to the manufacturer's instructions. Perforations were initiated by the initial drill, followed by the drills $2.0 \mathrm{~mm}, 3.5 \mathrm{~mm}$, 2.8/3.5mm and $3.75 \mathrm{~mm}$, with undersized site preparation technique. Two 3.75 x 20mm GM Helix Long Neoporos implants (Neodent, Curitiba, Brazil) were placed in the regions of teeth \#15 (Figure 3.A) and \#25 and two $3.75 \times 13 \mathrm{~mm}$ GM Helix Acqua implants (Neodent) in the regions of teeth \#12 and \#22. The four implants were placed $2 \mathrm{~mm}$ subcrestally and anchored apically in the region of the paranasal bone with an insertion torque of 60 N.cm. 


\section{FINAL PROSTHETIC PHASE}

Due to the high initial implant stability obtained, it was possible to apply the immediate loading technique. Two GM Mini Conical Abutments of 30 degrees with $2.5 \mathrm{~mm}$ transmucosal height (Neodent) were used on the implants of sites \#15 and \#25 and two GM Mini Conical Abutment of 17 degrees with $2.5 \mathrm{~mm}$ transmucosal height (Neodent) were used in implants of sites \#12 and \#22 (Figure 3.B). The upper arch was sutured with 5.0 resorbable suture thread. Then, four open-tray impression copings were placed on the abutments and joined to the multifunctional guide in occlusion with the lower arch using Pattern acrylic resin (GC America Inc, Alsip, USA). The impression was performed with condensation silicone Speedex (Coltene, Altstätten, Switzerland) and sent to the prosthesis laboratory.

A passive fit technique was used to fabricate the prostheses. The mini abutment analogs (Neodent) were positioned in the transfers that were held in the impression material, and the definitive cast was obtained with artificial gingiva in place. Subsequently, the brass copings of the passive fitting technique (Neodent) were screwed to the analogs, and the castable coping was adapted over the brass ones. The framework was waxed and then soldered and adapted onto the brass copings of the working cast. The prosthetic teeth were mounted according to the intraoral clinical evaluation. The prosthesis was processed. The brass copings were removed and titanium copings (Neodent) were screwed into the working cast. The access holes were sealed, and the framework was cemented over the titanium copings with an adhesive resin cement (Panavia; Kuraray America Inc.) (11). This technique compensates for any distortion inherent in 1-piece castings by luting the framework to the titanium cylinder, which has a smalle dimension than the brass coping used during the framework waxing (12). The prosthesis was finished. Although it was screw retained, a precise fit was achieved because the cement compensated for any casting distortions. After 24 hours, the patient returned with good healing of the upper arch (Figure 3.C) and a try-in of the teeth fixed with wax to the metal bar was performed.

Forty-eight hours thereafter, the teeth were tried in, fixed with wax to the metal bar and on the third day the final prosthesis was inserted, according to the passive fit technique. Occlusal adjustments were performed, relieving excessive contact in excursive movements during the osseointegration period, but keeping the prosthesis in occlusion (Figure 4.A, Figure 4.B and Figure 5).

The patient returned with 14 days post-surgery to remove the suture and assess the clinical and radiographic condition of the rehabilitation. After 30 days and 6 months, success of implants and rehabilitation, favorable remodeling of the peri-implant tissues and satisfactory aesthetic and functional conditions were observed (Figure 6 and Figure 7). 


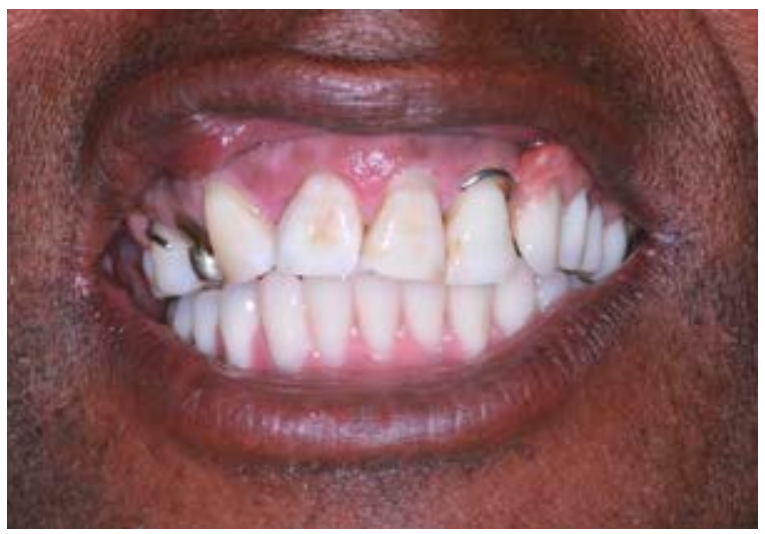

Figure 1. Initial smile of the patient showing the aesthetic condition.
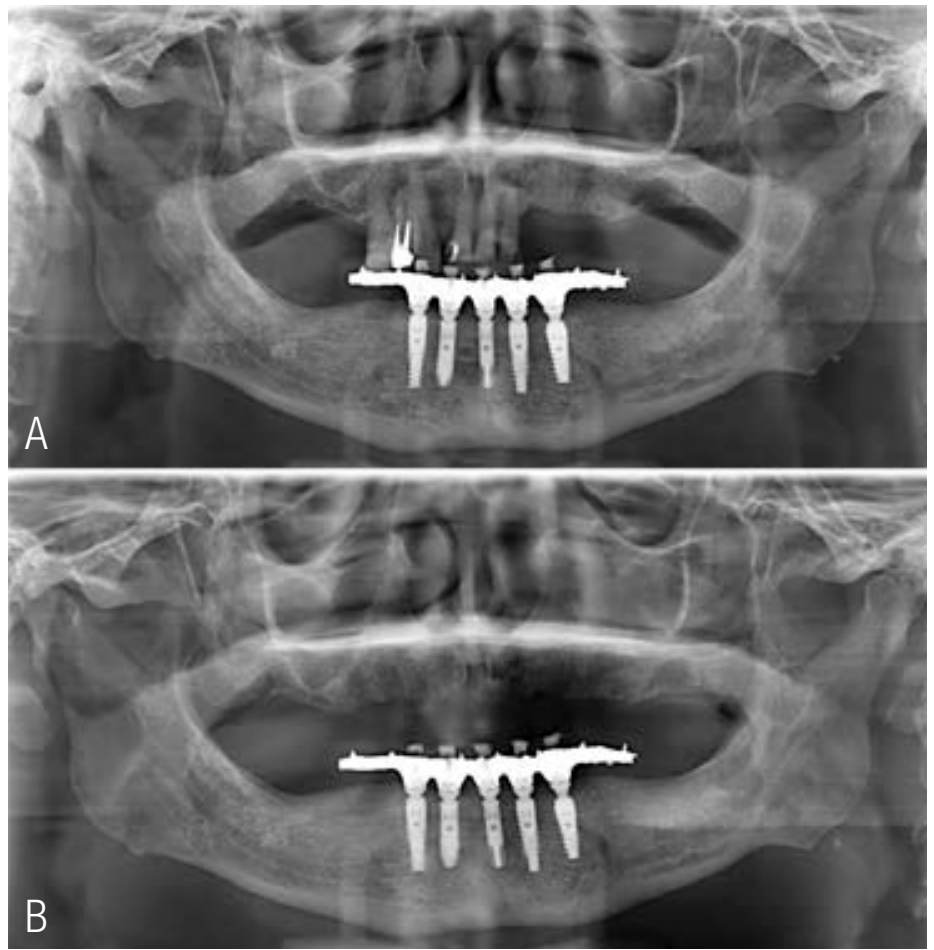

Figure 2. Initial panoramic radiograph of the case $(A)$, and panoramic radiograph 6 months after upper jaw teeth extractions $(B)$.

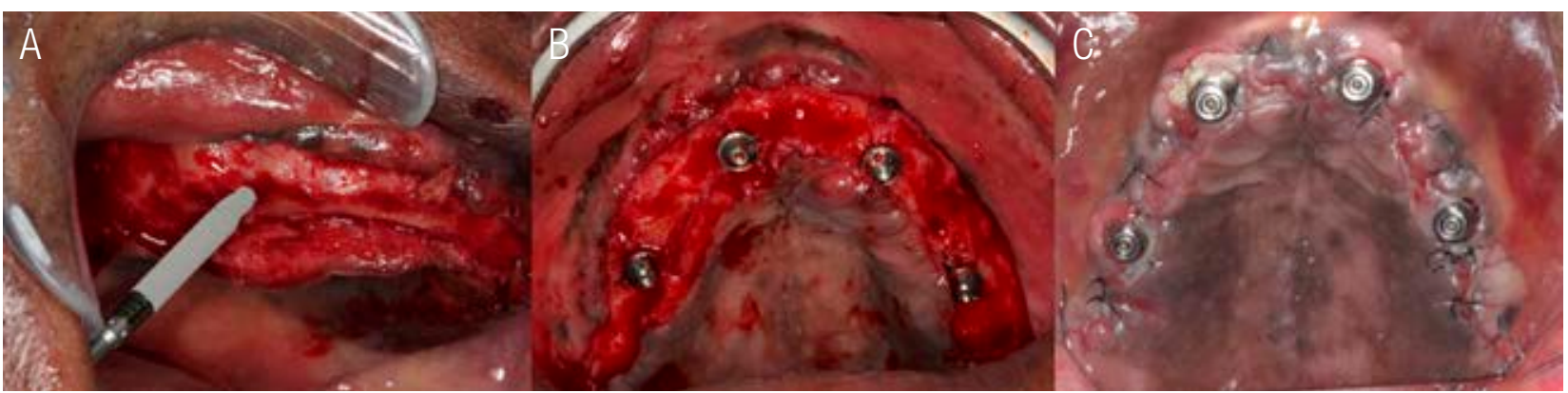

Figure 3. Placement of the extra-long implant on the right side (A), spatial distribution of the implants in the upper jaw (B), and occlusal view of the upper jaw 24 hours after surgery $(C)$. 


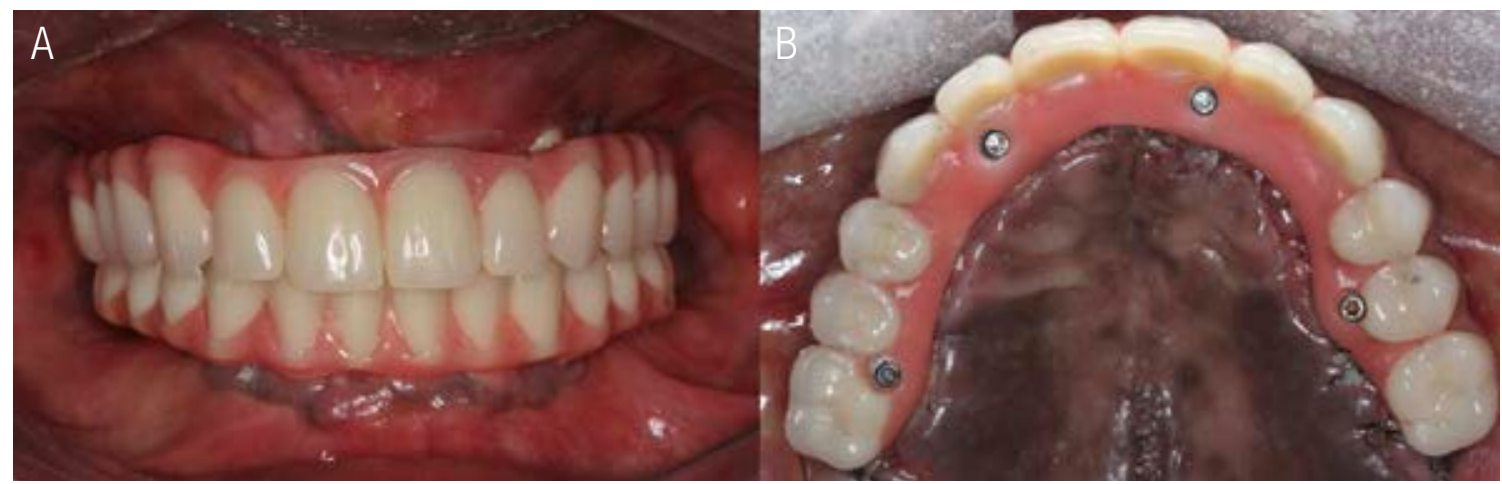

Figure 4. Front view of the installed prosthesis (A), occlusal view (B).

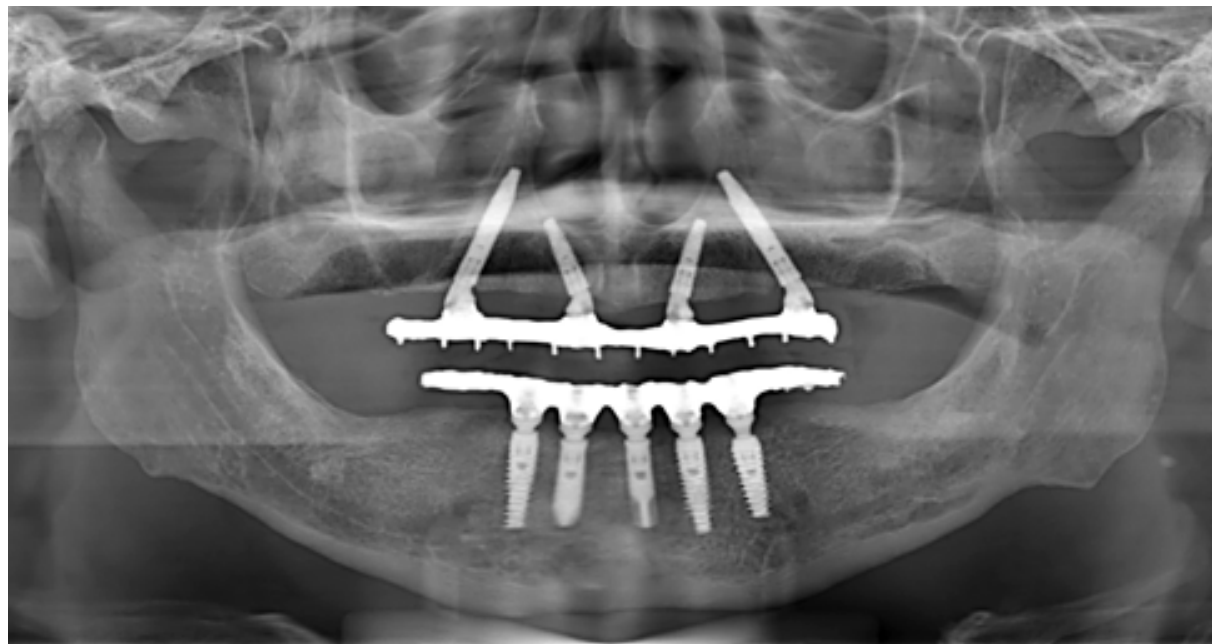

Figure 5. Panoramic radiograph of the immediate postoperative period.

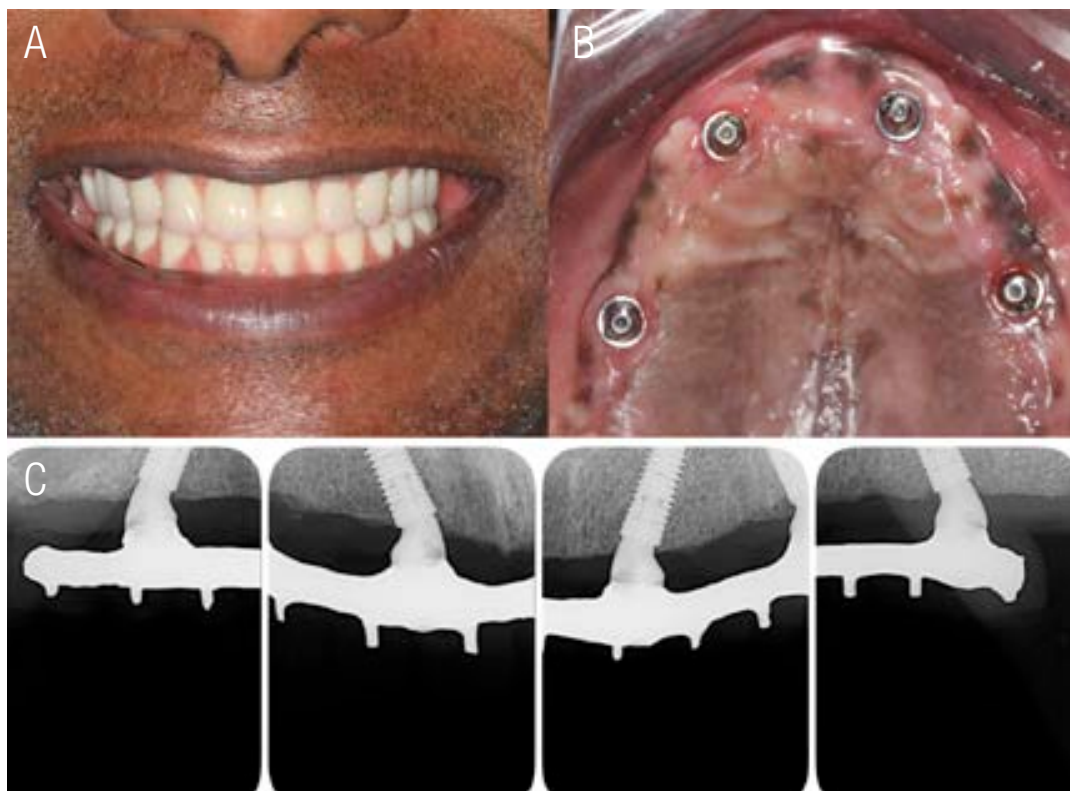

Figure 6. Patient's smile after 30 days (A), occlusal view of the soft tissues after 30 days (B), and periapical radiographs showing bone remodeling at 30 days (C). 


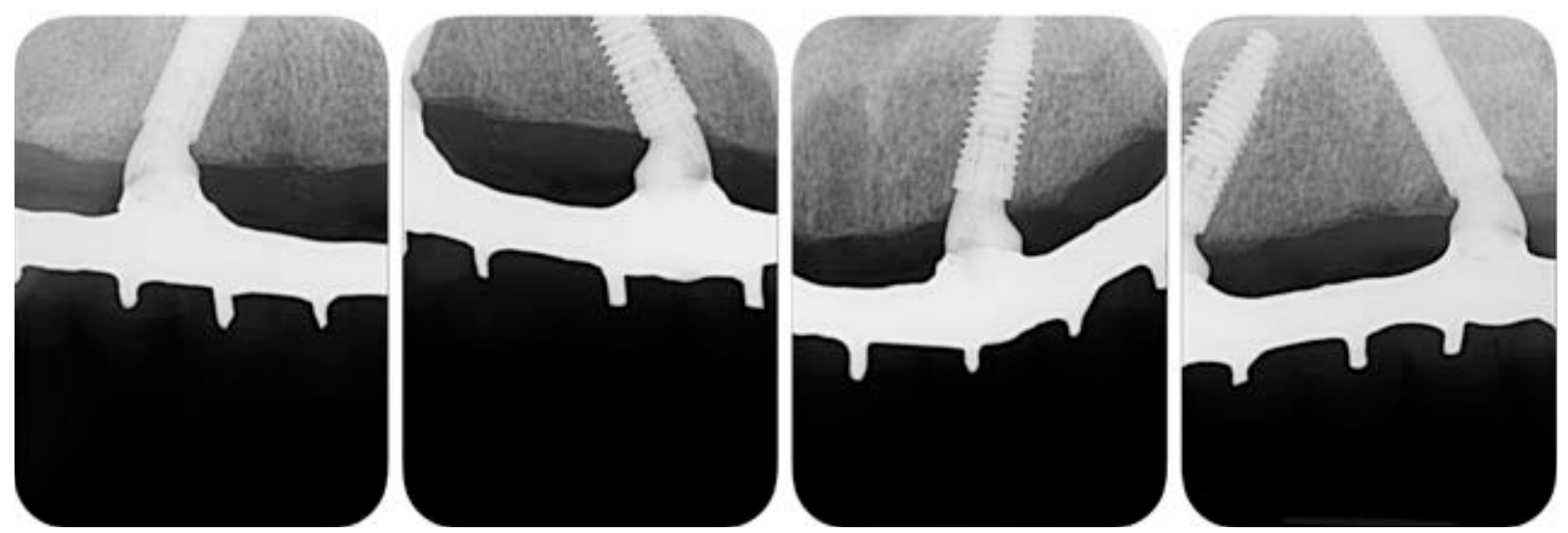

Figure 7. Periapical radiographs showing bone remodeling after 6 months.

\section{DISCUSSION}

The rehabilitation of the patient reported in this case presented a high degree of difficulty, as the low quality of the bone, severe resorption of the upper jaw, with the pneumatization of the maxillary sinuses, always raises questions about the performance or not of bone grafts (4-6). The upper jaw bone was of low quality (type III), resulting in concerns with respect to obtaining adequate primary stability, which is so essential for immediate loading and, consequently, osseointegration. However, restoring the patient's immediate masticatory function and aesthetic was important for the success of rehabilitation.

Milling accuracy is an important factor, which increases the likelihood of obtaining adequate primary stability and an ideal implant position (13). The macrogeometry of the implants used in the present case report, showing compacting threads in the cervical portion and, in the apical portion, cutting threads, was also a major factor to achieve an ideal primary stability (14). In addition, the positioning of the implants $2 \mathrm{~mm}$ below the bone crest may influence positively the maintenance of peri-implant tissues (15).

Longer implants results in a reduction in stress transmitted to the bone, both in immediate and late loading protocols (16). With the evolution of implantology, extra-long implants of 20 to 25 $\mathrm{mm}$ were developed (8), which increased the probability of immediate loading of the prosthesis, satisfying the patient both functionally and aesthetically $(7,8)$. In the present case report, the implants had a diameter of $3.75 \mathrm{~mm}$, and presented two different lengths, two were 13-mm-long implants (anterior region) and two were extra-long 20-mm implants (posterior regions). As a result, the apical anchoring of the implants occurred in the paranasal bone. The increased length of the implants can be important, since it has been reported that in a combination of low bone quality of the upper jaw and exposure to high occlusal loads, rehabilitation with short implants represents one of the most frequent causes of failure (17). Therefore, the placement of posterior long-length implants was an important factor for the cortical anchoring and the installation of the immediate prosthesis.

Extra-long implants placed tilted have been recommended to obtain high levels of primary stability in the upper jaw arch, avoiding bone graft procedures (18). From a biomechanical point of view, this situation can be extremely important (18). The tilted placement of the implants and the angled abutments provided the decrease in the length of the cantilevers in this case report, an 
important factor to avoid fractures of the metal bar (19). In addition, radiographic images have shown that the remodeling of the upper jaw bone around tilted implants is minimal (20).

The number of implants and positioning has also been the subject of studies on complete implant-supported rehabilitation $(20,21)$. The compressive forces applied to the anterior and distal implants are the same in configurations with 4,5 or 6 implants, provided that the distal implants are close to the molar region $(18,20)$. In another study it was reported that the use of 4 implants towards the midline, including 2 implants placed $V$-shaped on the nasal crest and 2 implants placed on a M-shaped point on the piriform edge bilaterally, showed good stability after 1 year (20). In the current case report, the distal implants were placed tilted, being positioned closer to the molar region, reducing the cantilever, with the intention of providing a more favorable stress distribution on the prosthesis, implants and bone $(7,16)$.

Immediate loading of the prosthesis has been widely used, as surgery in two surgical stages generates greater stress for the patient due to the number of procedures performed (21). There is scientific evidence stating that the placement of the implant with immediate loading favors the maintenance of tissue volume by the micro stimulus generated in the bone (22-24). Therefore, immediate loading was important for maintaining the hard and soft tissues around the implant in the case presented.

Finally, an important challenge is to obtain a passive fit of the prosthesis (11), which is important for the long-term success of full-arch prostheses supported by implants (25). However, achieving this passive fit for the metal structure is one of the most complex tasks in implantology (26). This could be resolved by cutting and welding the structure at different points, and sometimes it is not always possible to obtain a fully passive structure $(11,26)$. The prosthesis of the current case report was installed according to the passive fit technique, which is important to avoid maladjustments and fractures of the metal structure.

\section{CONCLUSIONS}

The present report supported the use of conventional-length and extra-long implants, with internal tapered geometry, tilted and anchored in the paranasal bone, with immediate prosthetic loading, which proved to be a successful protocol for the treatment of an edentulous upper jaw, being able to minimize bone and tissue remodeling. In addition, it demonstrated that the use of extralong implants placed in a tilted position may be a viable alternative for bone grafts.

\section{CONFLICT OF INTEREST}

The authors have a conflict of interest because they work at the company that manufactures the implants used in this case report, however, they did not interfere in the results.

\section{FINANCIAL DISCLOSURE}

The authors declared that this case report has received no financial support.

\section{REFERENCES}

1. Sharan A., Madjar D. Maxillary sinus pneumatization following extractions: a radiographic study. Int $\mathrm{J}$ Oral Maxillofac Implants. 2008; 23 (1): 48-56.

2. Ozan O., Orhan K., Aksoy S., Icen M., Bilecenoglu B., Sakul B. U. The effect of removable partial dentures on alveolar bone resorption: a retrospective study with cone-beam computed tomography. J Prosthodont. 2012; 22 (1): 42-8. 
3. Cha H. S., Kim J. W., Hwang J. H., Ahn K. M. Frequency of bone graft in implant surgery. Maxillofac Plast Reconstr Surg. 2016; 38 (1): 19.

4. Gonzalez S., Tuan M. C., Ahn K. M., Nowzari H. Crestal approach for maxillary sinus augmentation in patients with $\leq 4 \mathrm{~mm}$ of residual alveolar bone. Clin Implant Dent Relat Res. 2014; 16 (6): 827-35.

5. Garg R., Mishra N., Alexander M., Gupta S. $\mathrm{K}$. Implant survival between endo-osseous dental implants in immediate loading, delayed loading, and basal immediate loading dental implants a 3-Year Follow-up. Ann Maxillofac Surg. 2017; 7 (2): 237-44.

6. Agliardi E. L., Romeo D., Panigatti S., de Araújo Nobre M., Maló P. Immediate full-arch rehabilitation of the severely atrophic maxilla supported by zygomatic implants: a prospective clinical study with minimum follow-up of 6 years. Int J Oral Maxillofac Surg. 2017; 46 (12): 1592-9.

7. Hsu A., Seong W. J., Wolff R., Zhang L., Hodges J., Olin P. S., et al. Comparison of initial implant stability of implants placed using bicortical fixation, indirect sinus elevation, and unicortical fixation. Int J Oral Maxillofac Implants. 2016; 31 (2): 459-68.

8. Maló P., de Araújo Nobre M., Lopes A., Rodriguez R. Preliminary report on the outcome of tilted implants with longer lengths (20-25 mm) in low-density bone: one-year follow-up of a prospective cohort study. Clin Implant Dent Relat Res. 2015; 17; Suppl 1: 134-42.

9. Castro D. S., Araujo M. A., Benfatti C. A., Araujo Cdos R., Piatelli A., Perrotti V., et al. Comparative histological and histomorphometrical evaluation of marginal bone resorption around external hexagon and Morse cone implants: an experimental study in dogs. Implant Dent. 2014; 23 (3): 270-6.

10. de Moura M. B., Rodrigues R. B., Pinto L. M., de Araújo C. A., Novais V. R., Júnior P. C.
S. Influence of screw surface treatment on retention of implant-supported fixed partial dentures. J Oral Implantol. 2017; 43 (4): 254-60.

11. Able F. B., de Mattias Sartori I. A., Thomé G., Moreira Melo A. C. Retrospective, cross-sectional study on immediately loaded implant-supported mandibular fixed complete-arch prostheses fabricated with the passive fit cementation technique. J Prosthet Dent. 2018; 119 (1): 60-6.

12. Berejuk H. M., Shimizu R. H., de Mattias Sartori I. A., Valgas L., Tiossi R. Vertical microgap and passivity off fit of three-unit implant-supported frameworks fabricated using different techniques. Int $\mathrm{J}$ Oral Maxillofac Implants. 2014; 29 (5): 1064-70.

13. Balshi T. J., Wolfinger G. J., Slauch R. W., Balshi S. F. A retrospective comparison of implants in the pterygomaxillary region: implant placement with two-stage, singlestage, and guided surgery protocols. Int J Oral Maxillofac Implants. 2013; 28 (1): 184-9.

14. Thomé G., Cartelli C. A., Vianna C. P., Trojan L. C. Retrospective clinical study of 453 novel tapered implants placed in all bone types: Survival rate analysis up to 2 years of follow-up. Int J Oral Maxillofac Implants. 2020; 35 (4): 757-61.

15. Martin C., Thomé G., Melo A. C., Fontão F. N. Peri-implant bone response following immediate implants placed in the esthetic zone and with immediate provisionalization--a case series study. Oral Maxillofac Surg. 2015; 19 (2): 157-63.

16. Kinsel R. P., Liss M. Retrospective analysis of 56 edentulous dental arches restored with 344 single-stage implants using an immediate loading fixed provisional protocol: statistical predictors of implant failure. Int $\mathrm{J}$ Oral Maxillofac Implants. 2007; 22 (5): 823-30.

17. van Steenberghe D., Jacobs R., Desnyder M., Maffei G., Quirynen M. The relative impact of local and endogenous patient-related 
factors on implant failure up to the abutment stage. Clin Oral Implants Res. 2002; 13 (6): 617-22.

18. Jensen O. T, Cottam J, Ringeman J, Adams M. Trans-sinus dental implants, bone morphogenetic protein 2, and immediate function for all-on-4 treatment of severe maxillary atrophy. J Oral Maxillofac Surg. 2012; 70 (1): 141-8.

19. Nicoli G., Piva S., Ferraris P., Nicoli F., Jensen O. T. Extra-long nasal wall-directed dental implants for maxillary complete arch immediate function: A pilot study. Oral Maxillofac Surg Clin North Am. 2019; 31 (2): 349-56.

20. Jensen O. T., Adams M. W., Butura C., Galindo D. F. Maxillary V-4: Four implant treatment for maxillary atrophy with dental implants fixed apically at the vomer-nasal crest, lateral pyriform rim, and zygoma for immediate function. Report on 44 patients followed from 1 to 3 years. J Prosthet Dent. 2015; 114 (6): 810-7.

21. Brunski J. B. Biomechanical aspects of the optimal number of implants to carry a crossarch full restoration. Eur J Oral Implantol. 2014; 7 Suppl 2: S111-31.
22. Benic G. L., Mir-Mari J., Hämmerle C. H. Loading protocols for single-implant crowns: a systematic review and meta-analysis. Int J Oral Maxillofac Implants. 2014; 29 (Suppl.): 222-38.

23. Han C. H., Mangano F., Mortellaro C., Park K. B. Immediate loading of tapered implants placed in postextraction sockets and healed sites. J Craniofac Surg. 2016; 27 (5): 1220-7.

24. Maló P., Lopes A., Araújo Nobre M., Ferro A. Immediate function dental implants inserted with less than $30 \mathrm{~N} . \mathrm{cm}$ of torque in full-arch maxillary rehabilitations using the All-on-4 concept: Retrospective study. Int J Oral Maxillofac Surg. 2018; 47 (8): 1079-85.

25. Thomé E., Lee H. J., Sartori I. A., Trevisan R. L., Luiz J., Tiossi R. A randomized controlled trial comparing interim acrylic prostheses with and without cast metal base for immediate loading of dental implants in the edentulous mandible. Clin Oral Implants Res. 2015; 26 (12): 1414-20.

26. Jain A. R., Nallaswamy D., Ariga P., Philip J. M. Full mouth rehabilitation of a patient with mandibular implant screw retained Fp-3 prosthesis opposing maxillary acrylic removable over-denture. Contemp Clin Dent. 2013; 4 (2): 231-5. 